\title{
The Reflection of Socio-Cultural Change in Batik Motifs
}

\author{
BaniSudardi \\ SebelasMaret University \\ banisudardi@yahoo.co.id
}

\begin{abstract}
Batik is a typical art, depicted on the cloth and attire. Batik cloth portrays various meanings and reflection of social events which inspire the making of batik. This paper discusses the reflection of sociocultural changes contained in batik motifs. The studied motifs are batik motif or coastal beach batik motif. Coastal motif is developed on the coast, especially in Pekalongan, Lasem, Indramayu, Cirebon which are currently centers of coastal batik production. Pekalongan is an area that has a long history in connection with the development of batik. Interaction with the Netherlands and Japan gave rise to unique batik. Beside of its position on the coast, Pekalongan receives many influences from Arab and China. Pekalongan batik reflects the dynamic progressive life. Lasem Batik has a more unique history of socio-cultural development. Lasem Batik is dominated by a thick Chinese influence. China in Lasem has a long history since the time of Majapahit and has immersed with the local population. China Lasem adopts batik with their own style. Meanwhile, Cirebon batik is a blend of Javanese batik, Chinese batik, and Java Cirebon. Cirebon batik is originally from Java, then inspired by the cultural values of Cirebon such as mega mendung (cloundy sky), singo barong, and of course marine biota. Cirebon is a reflection of three cultures, namely Java, Islam, and Hinduism. Cultural changes that occur in Indramayu batik are quite unique. This area is far from the source of batik so it has a more daring expression of batik. Indramayubatik is inspired by the nuances of marine life and the myths that occur in Indramayu.
\end{abstract}

Keywords:batik, socio-cultural, batik characteristics

\section{INTRODUCTION}

Batik is a typical form of art, depicted on cloth. The results of batik drawing can be used as clothing. In the beginning, batik is used as a garment to cover the lower part of the body from the stomach to the feet, but in its development, batik is also used to cover other parts of the body.

Along with the development of the times and changes in social life, batik has different functions and changes from time to time. At the beginning of its appearance, batik is part of a cultural ritual and is only used when attending a custom ceremony or a specific ritual. Certain batik motifs are only specifically assembled by certain officials such as kings and their subordinates. Today, batik is used anytime, anywhere and in any occasion. Batik that was once formal and magical is now experiencing a remarkable development. Batik can be utilized for various activities either profane or sacred.

All may occur due to the socio-cultural changes. Batik has changed its function and interpreted differently. The use of batik cloth has entered the realm of the development of diverse clothing style as fashion. Batik is used for upper, lower, skirt, kebaya (Javanese traditional woman upper attire) or can be produced for handicraft such as bed sheets, pillowcases, tablecloths, wall paintings, curtains, bags, hoods, shoes, sandals and handkerchiefs. The development of batik innovation makes batik become one of the influential economic objects in Indonesia. Some areas in Indonesia set batik as one of their cultural heritages.

Batik cloth and its patternrepresent the meaning and reflection of various social events that inspired its making. This paper discusses the reflection of sociocultural changes contained in batik motifs. The motif studied in this paperis a coastal batik or beach motif. Coastal motif is a kind of batik motif that develops in coastal areas, especially in Pekalongan, Lasem, Indramayu, and Cirebon, which are currently the centers of coastal batik in Indonesia.

\section{METHOD}

This study used descriptive qualitative method. The data of this research are all forms of information related to socio-cultural aspects in batik motif. The data were collected by interview, observation, and document review. To maintain the validity of the data, the researcher implemented data triangulation using various data sources. The results are then presented in the form of data descriptions.

\section{RESULT}

Pekalongan is an area that has a long history in relation to the development of batik. The interaction of the Pekalongan population with the Dutch and Japanese in earlier times has given rise to unique batik patterns. In addition, because of its location on the coast, Pekalongan received much influence from Arabs and Chinese who came as merchants at the time. Pekalongan batik reflects the progressive and dynamic life. Batik Pekalongan is unique because it is influenced by Chinese and Dutch 
culture at once. In its history, Chinese and Dutch used batik as their clothing. The Chinese use batik as tokwi or cloth covering table prayer [1].

In the socio-cultural aspects, Pekalongan batik received four influences, namely the influence of China, Yogya-Solo, Netherlands, and Japan. The Chinese influence can be easily understood and traced because, since ancient times, many Chinese settled on the coast. These Chinese people are also interested in batik and develop batik according to their taste. This Chinese batik is often called batik encim. This batik takes inspiration from Chinese paintings such as dragons, hong birds, banji, kilns, butterflies, Chinese legends, and so on.

When designing batik motifs, Chinese batik artisans in Pekalongan were greatly influenced by the culture of their ancestors such as traditional belief and legend. Typical Chinese motifs are: Hong bird motif that symbolizes love, kilin motif (animals that resemble threelegged dogs, or sometimes appear four-legged but one leg is as a wand) which is the incarnation of Khong $\mathrm{Hu}$ Chu prophet who meditates in Tibet mountain, and the dragon motif that symbolizes power. The motifs are also inspired by classical Chinese stories such as Sam Pek Eng Tey.

Originally, Pekalongan batik was identified by batik Encim, which is batik worn by Chinese descendants elder women. This reflects a local wisdom called the empan papan which in Indonesian, is expressed by the saying: 'di mana bumi dipijak di situ langit di junjung' (a person needs to adapt to his/her place of living). Chinese ethnic in Pekalongan is actively wearing and supporting the development of Javanese batik because they are in Java Island following the Javanese tradition. However, their batik is somehow unique because they have another culture source that is Chinese culture.

In addition, Pekalongan batik has traditional motifs that are influenced from Yogya and Solo batik motifs. If Yogya and Solo batiks are colored soga brown, then this Pekalongan batik has a colorful pattern up to 8 types of color. Traditional batiks still appear in traditional patterns, such as decoration of lar (wings), parang, sidomukti, meru and so on with little changes according to styles. The Dutch also use batik as everyday clothes, but adapted to their traditions and culture. Some Dutch people become batik skipper and produce typical Dutch batik. Some of them are Zuylen, Metz, and Yan. Some elements of Dutch were immersed into batik motif, such as bouquet batik (buketan), chrysanthemum flowers, grapes, and bridge cards. There are even batik motifs based on European folklores such as Snow White, Red Princess, and Cinderella. Some other relevant Dutch patterns were also found in a variety of motifs of the Dutch soldiers' lines called kumpeni or VOC (Verenigde Oost Indsche Compagnie).

Another area that has a typical batik is Lasem. Unlike Pekalongan that is multicultural, Lasem batik reflects the adoption of Chinese culture into the tradition of batik. As the name implies, this batik is often referred to as Laseman batik. Laseman Batik is Lasem batik which in its development is influenced by elements of Chinese art and culture that came to Lasem and mingle with local culture. Based on the acculturation of the culture, a more positive and rich culture was developed, as the beginning of the birth of Laseman batik. Laseman batik is a batik that has distinctive Chinese motifs, which adopt Chinese mythological beliefs, such as Dragon animal, Lok Can, Peacock, Butterfly, Rose Plant, and Seruni Lotus. Batik technique is done by a mixture of variety of motifs without eliminating the characteristics and pattern of Lasem classical batik.

In accordance with the socio-cultural development of Lasem society, today's contemporary batik type is developed. This contemporary type of batik is batik whose pattern is not bound by traditional motifs. Contemporary batik is more influenced by current trend or contemporary fashion that displays a free expression. This batik is also known as batik CorakBaruatau Gaya Baru (new cut or new style) that is very diverse and highly demanded by all community groups. Some examples of contemporary Lasem batik motifs are Tiga Negeri (Three States), Pagi-Sore (Morning-Afternoon), Siang-Malam (Day-Night), and Tumpal Clorot.

Lasem batik that is influenced by Chinese culture, explains the relationship between Chinese and Javanese ethnics, not only socially, but also economically. Lasem batik that is produced specifically in Lasem has its typical red color that cannot be imitated by batik producer in other areas. Another distinct characteristic lies in its pattern, which is a combination of Chinese and local culture influences of northern coastal area of Lasem. The overseas Chinese traders who came to Lasem brought great influence to the batik style in Lasem. Later, many Chinese traders became batik entrepreneurs, while native people work aslabors.

Hong birds and dragon motifs are considered as original motifs of Laseman batik. Both are assumed as symbols of Chinese culture. The dragon is a symbol of power, courage, and supernatural strength. In addition, there is a frangipani flower motif with the philosophy that people will get shade and calm under the frangipani tree, even when it dies. Seaweed motif (latoh) has a philosophical meaning that humans continue to multiply and breed. Man cannot live individually, but always builds relationships with others. Humans integrate and co-exist with each other. These motifs are often used by elder Chinese women. Therefore, Laseman batik is often referred to as 'Batik Encik'. The social picture of Laseman's batik culture is reflected in the motive of 'watu pecah' (broken stone) which is the memory of Lasem community's hard labor when making AnyerPanarukan road by the Dutch force.

According to Doellah, Indramayu batik comes from the remains of Sultan Agung troops and is the influence of Mataram palace[2]. According to previous researches, Indramayu batik is a pure coastal batik. This region depends solely on livelihood from activities in the oceans. This batik is known as Dermayon. Batik production is done by the wives of fishermen in their leisure time. As it was born in the coastal environment, Indramayubatik tends to have large paintings to speed up 
work. There are no complicated details as a practical socio-cultural reflection. The main colors of batik are white and blue as reflection of the color of the sky and the sea where they live. Dermayon batik is mainly inspired by marine life and plantation such as fruits, pigeons, algae, shrimp, fish, cotton, peacock, and so on.

Batik that is developed in Cirebon is called Cirebon or Trusmi batik because it is designed especially in Trusmi area. Unlike Indramayu that is named after the pure coastal batik, Trusmi batik also reflects Cirebon as a metropolitan city in the 16 th century. Cirebon is a sultanate district which was formerly considered as Demak area. As Demak kingdom was getting weak due to civil war and when the Kingdom capital was shifted to Pajang (inland), Cirebon self-proclaimed its independence and did not submit to Demak since Demak was devastated.

The most famous motif in Cirebon is mega mendung (clouds) motif. This motif is a picture of the nature. This motif is a symbol of protection, in which during the scorching sun, the emergence of clouds will protect humans from the heat of the sun. In addition, clouds are also symbols of the coming rain. The arrival of rain is a form of hope for the prosperity of the region.

Two things that become the typical motif of Cirebon is the motif that is sourced from two sultanates in Cirebon. The two sultanates are Kasepuhan Cirebon and Kanoman Cirebon, which are the result of regional divisions resulting from family conflicts. The symbol of Kasepuhan Sultanate is Singo Barong while the symbol of Kanoman Sultanate is Paksi Naga Liman. Both Singo Barong and Paksi Naga Liman have similar shapes. Singo Barong and Paksi NagaLiman is a fantasy animal in the form of a combination of several types of animals. This fantasy animal has a lion-shaped body, dragonmouth, elephant-head, and withBuroq wings. This animal is a symbol of the social situation of the multi-cultural community in Cirebon. Buroqelement that became the main body is the symbol of the Muslim community which is the main population of Cirebon. However, this specific Buroq has lion or tiger body. The tiger is the symbol of King Siliwangi who is the ancestor of the Sundanesetribe because he was the last Pajajaran king. The elephant is the symbol of Indian merchant, while the dragon is a symbol of Chinese culture.

\section{CONCLUSION}

As a form of art, batik reflects socio-cultural changes that occur in the community of its artists. Various things that happened before have been recorded and written in batik motif. From the existing phenomenon, it appears that batik motive is more inclined to record socio-cultural changes symbolically. There are complicated things that are difficult to explain to know the reasons for an event recorded in batik motif. Batik tends to record things that have settled in the memory of society. In this case, we see that there is a multilevel form of symbolization. For example, Paksi Naga Liman and Singa Barong patterns are the sublimation of Cirebon culture. The sublimation of the culture then inspires the emergence of the unique motifs of Paksi Naga Liman and Singa Baron.

\section{ACKNOWLEDGEMENT}

A sincere gratitude is sent to the Directorate General for Research and Development at the Ministry of Research, Technology and Higher Education, that has provided funds in the grant scheme for postgraduate program.

[1] Danandjaja, James. Folklor Indonesia: Ilmu Gosip, Dongeng, dan lain-lain. Jakarta: Grafitipers, 1986.

[2] Doellah, H. Santosa. Batik: The Impact of Time and Enviroment. Surakarta: Danarhadi, 2002.

[3] Djoemena, NianS. Ungkapan Sehelai Batik Its Mystery and Meaning. Jakarta: Djambatan, 1990.

[4] Hitchcock, Michael. Indonesia Textiles. Findon: Periplus Edition, 1991.

[5] Maxwell, Robyn. Textiles of Souteast Asia: Tradition, Trade and Transformation. Singapore: Periplus, 1990.

[6] Poerbatjaraka, R.M.Ng. KapustakanDjawi. Jakarta: Djambatan, 1952.

[7] Pujiyanto. Batik Keraton Kasunanan dan Mangkunegaran Surakarta: Sebuah Tinjauan Historis, Sosial Budayadan Estetika. Yogyakarta: Kendil,2010. 